\title{
Mutations in the isocitrate dehydrogenase 2 gene and IDH1 SNP 105C > T have a prognostic value in acute myeloid leukemia
}

Kerstin Willander ${ }^{1,3^{*}}$, Ingrid Jakobsen Falk², Roza Chaireti ${ }^{3}$, Esbjörn Paull ${ }^{4}$, Monica Hermansson ${ }^{5}$, Henrik Gréen ${ }^{2,6}$, Kourosh Lotfi ${ }^{2,3}$ and Peter Söderkvist ${ }^{1,7}$

\begin{abstract}
Background: The isocitrate dehydrogenase (IDH1/IDH2) genes are metabolic enzymes, which are frequently mutated in acute myeloid leukemia (AML). The enzymes acquire neomorphic enzymatic activity when they mutated.

Methods: We have investigated the frequency and outcome of the acquired IDH1/IDH2 mutations and the IDH1 SNP 105C > T (rs11554137) in 189 unselected de novo AML patients by polymerase chain reaction amplification followed by direct sequencing. The survival are presented in Kaplan Meier curves with log rank test. Multivariable survival analysis was conducted using Cox regression method, taking age, risk group, treatment, IDH1/2 mutations and IDH1 SNP105 genotype into account.

Results: Overall, IDH1/2 mutations were found in 41/187 (21.7\%) of the AML patients. IDH1 codon 132 mutations were present in $7.9 \%$, whereas $1 \mathrm{DH} 2$ mutations were more frequent and mutations were identified in codon 140 and 172 in a frequency of $11.1 \%$ and $2.6 \%$, respectively. The SNP 105C > T was present in $10.5 \%$ of the patients, similar to the normal population. A significantly reduced overall survival (OS) for patients carrying IDH2 codon 140 mutation compared with patients carrying wild-type IDH2 gene $(p<0.001)$ was observed in the intermediate risk patient group. Neither in the entire patient group nor subdivided in different risk groups, IDH1 mutations had any significance on OS compared to the wild-type IDH1 patients. A significant difference in OS between the heterozygous SNP variant and the homozygous wild-type was observed in the intermediate risk FLT3 negative AML patients $(p=0.004)$.
\end{abstract}

Conclusions: Our results indicate that AML-patients with IDH2 mutations or the IDH1 SNP 105C > T variant can represent a new subgroup for risk stratification and may indicate new treatment options.

Keywords: AML, IDH1, IDH2, SNP, Prognostic markers

\section{Background}

Acute myeloid leukemia (AML) is a hematological malignancy caused by acquired genetic alterations in genes affecting the normal proliferation and terminal differentiation of myeloid progenitor cells. Based on cytogenetic abnormalities, cases of AML are usually classified into three groups, with favorable, intermediate and adverse

\footnotetext{
* Correspondence: kerstin.willander@liu.se

'Department of Clinical and Experimental Medicine, Linköping University, Linköping, Sweden

${ }^{3}$ Department of Hematology, County Council of Östergötland, Linköping, Sweden

Full list of author information is available at the end of the article
}

prognosis [1]. The largest group is the intermediate risk group in which patients with cytogenetically normal karyotype (CN-AML) constitute about $45 \%$ of de novo AML [2,3]. These patients form a heterogeneous group where some achieve complete remission and become long term survivors, while others rapidly relapse, often with a more aggressive or resistant disease. The overall 5 -year survival is $35-40 \%$, but less than $15 \%$ in AML patients above the age of 60 [4]. During the last decades, several new mutations with prognostic impact have been identified in AML. These include internal tandem duplications (ITDs) in the fms-like tyrosine kinase 3 (FLT3) 
gene, conferring an adverse prognosis, and nucleophosmine 1 (NPM1) gene mutations, which in the absence of FLT3-ITD confer a favorable prognosis [5-8]. Both these genes have become clinically established prognostic markers in CN-AML. However, there is still a large group of intermediate risk patients without FLT3-ITD/NPM1 mutations or other reliable prognostic markers, highlighting the need for additional markers that could explain the differential outcome in this heterogeneous patient group.

Genome-wide analysis in patients with AML have identified further genetic markers, thus extending the possibilities for more accurate prognostic distinctions between subgroups, and might aid the clinicians in treatment decisions such as choice of chemotherapy regime or early stem cell transplantation (SCT).

The isocitrate dehydrogenase $(I D H) 1$ and 2 genes were identified to be mutated in AML [9]. The IDH family consists of three isoforms, IDH1, IDH2 and IDH3 where IDH1 is located in the cytosol, while IDH2 and IDH3 are located in the mitochondrion and are normally involved in citrate metabolism in the tricarboxylic acid cycle [10]. The IDH1 and IDH2 enzymes are encoded by the $I D H 1$ gene at chromosome $2 \mathrm{q} 33$ and the $I D H 2$ gene resides at chromosome $15 \mathrm{q} 26$. The enzymes are $\mathrm{NADP}^{+}$-dependent to catalyze isocitrate oxidation to $\alpha$-ketoglutarate $(\alpha-K G)$ and the cofactor NADPH is generated. Mutations in the $I D H 1$ genes were first identified in malignant gliomas [11,12] and subsequently IDH1 mutations were frequently found in AML [9] and later also recurrent $I D H 2$ mutations were found in AML [13-15]. No mutations have been reported in the $I D H 3$ gene. IDH1/2 mutations are usually heterozygous with one wild-type allele and one mutant allele, affecting the arginine at codon 132 in exon 4 in the IDH1 gene, codon 140 and codon 172 in exon 4 in the IDH2 gene. The mutants acquire neomorphic enzymatic activity by converting $\alpha-K G$ to 2-hydroxyglutarate (2-HG) $[16,17]$. Studies have shown that IDH1/2 mutations are associated with epigenetic alterations, by inhibiting the function of TET2, a DNA demethylase enzyme which activity is dependent on $\alpha-K G$ and essential for DNA demethylation. Mutations in the IDH1 or IDH2 genes favour 2-HG production and decrease the amount of $\alpha-K G$, resulting in a hypermethylation phenotype and impaired hematopoietic differentiation [18,19]. Further, a synonymous single nucleotide polymorphism (SNP) (rs11554137) located in codon 105 in exon 4 in the IDH1 gene, was recently reported to be of prognostic value in both adult and paediatric AML patients [20,21].

In this study we aimed to investigate the frequency of the acquired IDH1 and IDH2 mutations and the SNP $105 \mathrm{C}>\mathrm{T}$ (rs11554137) located in the IDH1 gene and correlate the different genotypes to the outcome in AML patients.

\section{Results}

\section{$I D H 1$ and IDH2 mutation analysis}

All patients were successfully genotyped for $I D H 1$ codon 132 mutations, IDH2 codon 140 and codon 172 mutations, and for the IDH1 codon 105 SNP (rs11554137) (Table 1). Mutational data distributions in the entire cohort and in patient subgroups are presented in Table 2. In total, IDH1/2 mutations were found in 41/189 (21.7\%) of the AML patients. Fifteen patients (7.9\%) had mutations in codon 132 in the $I D H 1$ gene resulting in four different amino acid exchanges, arg $>$ his $(7 / 15)$, $\arg >$ cys $(6 / 15), \arg >$ leu $(1 / 15)$ and $\arg >$ gly $(1 / 15)$. $I D H 2$ mutations were found in exon four at codon 140 in $21(11.1 \%)$ of the patients and at codon 172 in 5 (2.6\%) of the patients. For IDH2 codon 140 mutations, two amino acid exchanges were detected: $\arg >\operatorname{gln}(20 / 21)$ and $\arg >$ gly $(1 / 21)$. For $I D H 2$ codon 172 mutations all were $\arg >$ lys exchanges (5/5). Mutations in the $I D H 1$ gene were mutually exclusive with mutations in the $I D H 2$ gene (Table 1).

No significant differences between $I D H$ genotype groups in terms of median age at diagnosis, gender, treatment regime, or distribution of FLT3/NPM1 mutations were found in the patient cohort. However, the median age at diagnosis appear to be higher in patients with mutated $I D H$ gene (IDH1 or IDH2) than in patients with wild-type $I D H$ gene ( 69 vs. 62 years, respectively, $\mathrm{p}=0.036$, Table 2 ).

\section{Impact of IDH1 and IDH2 mutations on treatment response and overall survival}

We found no significant difference on OS for patients with IDH1 codon 132 mutations, neither in the entire group nor when stratified in different risk groups.

Mutations in the $I D H 2$ gene codon 140 revealed a significant increased risk for shorter OS in the whole patient group in relation to the wild type IDH2 codon 140, $(\mathrm{HR}=1.94 ; 1.07-3.53 ; 95 \%$ confidence interval, $\mathrm{p}=0.03$ ) (Cox regression Table 3; 15 patients with missing karyotype data where excluded from the analysis). This was most pronounced among the intermediate risk group

Table 1 IDH1 and IDH2 mutations and SNP 105C > T in 189 AML patients

\begin{tabular}{llll}
\hline Gene & Nucleotide change & Amino acid change & Number of patients \\
\hline IDH1 & CGT $>$ TGT & R132C & 7 \\
IDH1 & CGT $>$ CAT & R132H & 6 \\
IDH1 & CGT $>$ GGT & R132G & 1 \\
IDH1 & CGT $>C T 1$ & R132L & 1 \\
IDH2 & $C G G>C A G$ & R140Q & 20 \\
IDH2 & $C G G>G G G$ & R140G & 1 \\
IDH2 & AGG $>$ AAG & R172K & 5 \\
IDH1 & $G G C>G G T$ & G105G & 20 \\
\hline
\end{tabular}


Table 2 Patient characteristics and distributions of IDH mutations for all patients and within groups

\begin{tabular}{|c|c|c|c|c|c|c|c|c|c|}
\hline \multirow{2}{*}{$\begin{array}{l}\text { CHARACTERISTIC } \\
\text { Total } \mathbf{n}=189 \\
\end{array}$} & \multirow[t]{2}{*}{ All } & \multicolumn{2}{|c|}{ IDH1 codon 132: } & \multicolumn{2}{|c|}{$\begin{array}{c}\text { IDH1 codon } 105 \\
\text { (synonymous SNP): }\end{array}$} & \multicolumn{2}{|c|}{ IDH2 codon 140: } & \multicolumn{2}{|c|}{ IDH2 codon 17} \\
\hline & & Wild type & Mutation & Wild type & Variant & Wild type & Mutation & Wild type & Muta \\
\hline Age median (range), years & 64 (19-88) & $63(19-85)$ & $70(30-88)^{*}$ & $64(19-88)$ & $66(29-84)$ & $63(19-88)$ & $66(37-83)^{*}$ & $64(19-88)$ & $72(46$ \\
\hline \multicolumn{10}{|l|}{ Gender } \\
\hline Male & 95 & 90 & 5 & 85 & 10 & 85 & 10 & 92 & 3 \\
\hline Female & 94 & 84 & 10 & 84 & 10 & 83 & 11 & 92 & 2 \\
\hline \multicolumn{10}{|l|}{ Karyotype } \\
\hline Normal & 108 & 99 & 9 & 95 & 13 & 96 & 12 & 106 & 2 \\
\hline Aberrant & 75 & 69 & 6 & 68 & 7 & 66 & 9 & 72 & 3 \\
\hline Missing data & 6 & 6 & & 6 & & 6 & & 6 & \\
\hline \multicolumn{10}{|l|}{ Risk group } \\
\hline Low & 32 & 31 & 1 & 30 & 2 & 29 & 3 & 31 & 1 \\
\hline Intermediate & 87 & 80 & 7 & 72 & 15 & 75 & 12 & 86 & 1 \\
\hline High & 55 & 51 & 4 & 52 & 3 & 51 & 4 & 52 & 3 \\
\hline Missing data & 15 & 12 & 3 & 15 & & 13 & 2 & 14 & 1 \\
\hline \multicolumn{10}{|l|}{ FLT3 status } \\
\hline FLT3 wild type & 116 & 109 & 7 & 104 & 12 & 101 & 15 & 114 & 2 \\
\hline FLT3-ITD & 37 & 34 & 3 & 32 & 5 & 33 & 4 & 36 & 1 \\
\hline Missing data** & 36 & 31 & 5 & 33 & 3 & 34 & 2 & 34 & 2 \\
\hline NPM1 status & & & & & & & & & \\
\hline NPM1 wild type & 99 & 92 & 7 & 87 & 12 & 88 & 11 & 96 & 3 \\
\hline NPM1 mutation & 52 & 49 & 3 & 47 & 5 & 44 & 8 & 52 & 0 \\
\hline Missing data** & 38 & 33 & 5 & 35 & 3 & 36 & 2 & 36 & 2 \\
\hline
\end{tabular}

Induction treatment response

Complete remission
Not complete remission
Missing information

$\begin{array}{cc}132 & 122 \\ 49 & 44 \\ 8 & 8\end{array}$

IDH1 codon 132

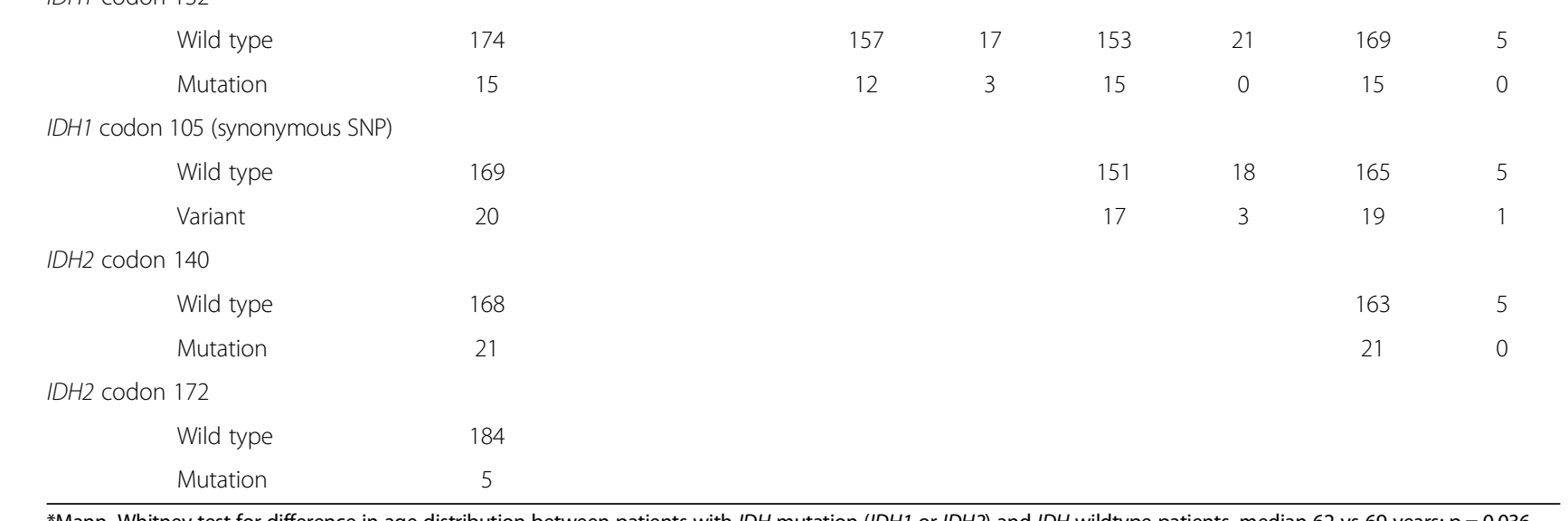

10
5
0

119
43
7

$\begin{array}{ccccc}13 & 119 & 13 & 127 & 5 \\ 6 & 43 & 6 & 49 & 0 \\ 1 & 6 & 2 & 8 & 0\end{array}$

*Mann-Whitney test for difference in age distribution between patients with $I D H$ mutation $(I D H 1$ or IDH2) and IDH wildtype patients, median 62 vs 69 years; $\mathrm{p}=0.036$. **FLT3-ITD and NPM1 mutations were not routinely analyzed in all non-normal karyotype patients.

patients with a median OS 6 vs. 18 months, for mutated and wild type patients, respectively, $\mathrm{p}=0.001$, (Figure $1 \mathrm{~A}$; entire cohort presented in Figure 1B). Patients with IDH2 codon 172 mutations showed an improved survival in the entire patient group compared to patients with wild type IDH2 codon 172 in cox regression analysis $(\mathrm{HR}=0.22$; 0.07-0.74; 95\% confidence interval, $\mathrm{p}=0.014$ ) (Table 3) and Kaplan Meier analysis, $(\mathrm{p}=0.09$, Figure 2). 


\begin{tabular}{|c|c|c|c|c|}
\hline Covariates & $N$ & $H R$ & $95 \% \mathrm{Cl}$ & $p$ \\
\hline Age & & 1.022 & $1.002-1.042$ & 0.033 \\
\hline \multicolumn{5}{|l|}{ Risk group } \\
\hline Low risk & 32 & 1 & & \\
\hline Intermediate risk & 87 & 2.980 & $1.495-5.942$ & 0.002 \\
\hline High risk & 55 & 5.993 & $2.912-12.333$ & $<0.001$ \\
\hline \multicolumn{5}{|l|}{ Treatment } \\
\hline Chemotherapy & 118 & 1 & & \\
\hline Chemotherapy + allo-SCT & 56 & 0.231 & $0.118-0.450$ & $<0.001$ \\
\hline \multicolumn{5}{|l|}{ IDH1 codon 132} \\
\hline Wild type & 162 & 1 & & \\
\hline Mutated & 12 & 0.816 & $0.390-1.708$ & 0.59 \\
\hline \multicolumn{5}{|l|}{ IDH2 codon 140} \\
\hline Wild type & 155 & 1 & & \\
\hline Mutated & 19 & 1.942 & $1.068-3.530$ & 0.030 \\
\hline \multicolumn{5}{|l|}{ IDH2 codon 172} \\
\hline Wild type & 169 & 1 & & \\
\hline Mutated & 5 & 0.222 & $0.067-0.738$ & 0.014 \\
\hline \multicolumn{5}{|c|}{ IDH1 SNP codon 105 GGC > GGT } \\
\hline Wild type & 154 & 1 & & \\
\hline Variant & 20 & 1.496 & $0.812-2.756$ & 0.196 \\
\hline
\end{tabular}

$95 \% \mathrm{Cl}=95 \%$ Confidence interval; $\mathrm{HR}=$ Hazard ratio.

Significant $P$-values $(P<0.05)$ in boldface.

There were no significant differences in the distribution of $I D H 1$ or $I D H 2$ genotypes among patients with $\mathrm{CR}$ and no CR.

\section{The IDH1 SNP variant influences overall survival}

All patients were successfully genotyped for IDH1 codon 105 SNP (rs11554137) (Table 1) that was not associated with the $I D H$ mutations (only 7 overlapping cases; 3 in $I D H 1$ and 4 in $I D H 2)$. The synonymous SNP (GGC > GGT) was found in 20 patients $(10.6 \%)$ in the entire cohort. Kaplan Meier curves with log rank tests also revealed a significant difference in OS between the IDH1 codon 105 SNP variants, where heterozygous carriers of the $\mathrm{T}$ allele displayed a shorter survival compared to patients with homozygous wild-type $\mathrm{C}$ alleles. This was significant only in the intermediate risk FLT3-ITD negative AML patients. In this risk group, the median OS was 20 vs. 6 months for codon 105 wild-type $\mathrm{C} / \mathrm{C}$ and variant $\mathrm{T} / \mathrm{C}$ patients, respectively, $(\mathrm{p}=0.004$, Figure 3$)$. It should be noted that all the intermediate risk FLT3-ITD negative patients with the codon $105 \mathrm{~T}$ allele were also negative for NPM1 mutations. However, in cox regression analysis the codon 105 SNP did not display independent significance due to other stronger factors affecting the outcome in the entire cohort (Table 3).

\section{Discussion}

Mutations in the $I D H 1$ and $I D H 2$ genes in AML are reported as being associated to diverse outcomes by different groups [22]. Mardis et al. [9] was the first to identify mutations in the $I D H 1$ gene as a new recurrent mutation associated with CN-AML. Further, Marcucci et al. [13] reported two different mutations in the IDH2 gene (R140 and R172) in AML. In the present study we have investigated the frequency and impact of $I D H$ mutations on outcome according to the different clinical risk groups, normal/aberrant cytogenetics, and also according to the FLT3 and NMP1 mutation status in 189 unselected AML patients. In our study cohort we found $I D H 1$ and $I D H 2$ mutated in $21.7 \%$ of the cases. IDH2 mutations were more common than $I D H 1$ mutations $(13.8 \%$ vs $7.9 \%)$. The frequency of $I D H 1$ mutations $(7.9 \%)$ in our AML cohort is similar to previous reports of unselected AML patients (5.5\%-10.4\%) [9,14,15,17,23-26]. The IDH2 mutations have been reported to have a prevalence of $6.1 \%-17.7 \%$ in unselected AML [15,17,24-28], as compared to $13.8 \%$ in our study group. Investigation of the influence on OS in the entire study population (no selection in karyotypes, risk groups or FLT3/NPM1 status) for IDH1 mutations conferred no significant difference compared to wild-type $I D H 1$, nor when statistical stratification was applied. In some studies, an influence on OS is seen with IDH1 mutations for patients with $\mathrm{CN}-\mathrm{AML}$ or intermediate risk group according to the FLT3/NPM1 status [13-15,23,28], while other groups could not detect any impact on survival with mutated $I D H 1$ gene, which is in accordance with our results $[9,20,24,26]$. Furthermore, in our cohort we also found a slightly higher median age at diagnosis in patients with mutated $I D H 1$ gene than in patients with wild type $I D H 1$. Our cohort covered a wide age span including both younger and older patients, but future studies investigating the impact of $I D H$ mutations specifically in older AML patients could be warranted.

Two hotspot mutations are found in exon 4 in the IDH 2 gene, R140 and R172. In our cohort we found R140 to be altered with a frequency of 21/189 (11.1\%) and R172 in 5/ 189 (2.6\%) patients. We found prognostic significance on OS for the IDH2 codon 140 mutations, where the intermediate risk patients with codon 140 mutations revealed a significantly shorter OS than codon 140 wildtype. IDH2 codon 172 mutations were identified in a low frequency, only in 5 individuals, and were provided with a favorable outcome in our study cohort. However, Ward et al. noted a trend toward improved survival for patients with $I D H 2$ codon 140 mutations and also Green et al. reported an unexpected favorable outcome associated with $I D H 2$ R140 mutations and an unfavorable outcome for patients with IDH2 R172 mutation [17,27]. Patel et al. also found a favorable effect for patients with mutant IDH2 codon 140 [29]. However, in the study of Green et al., there was a 

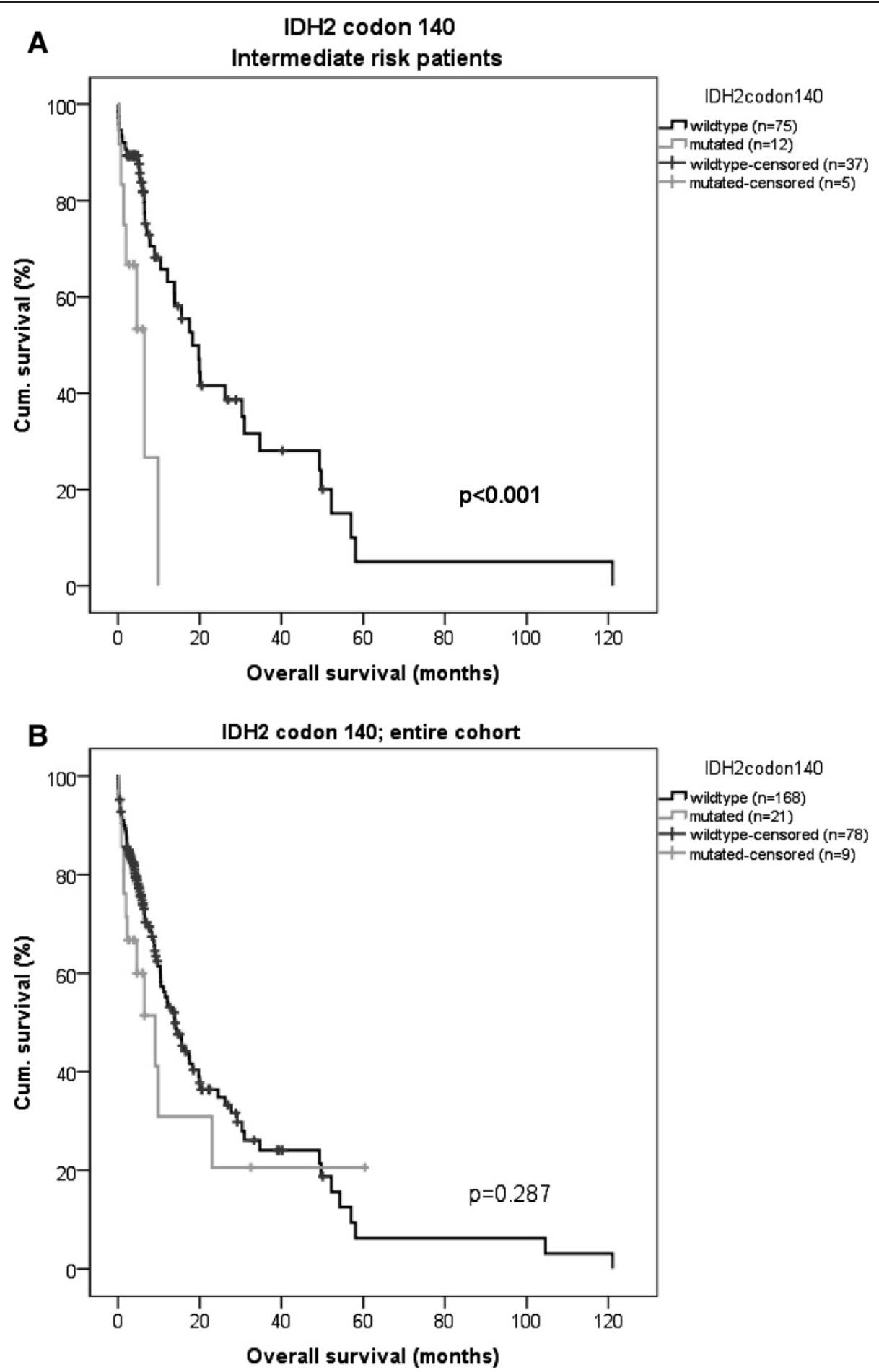

Figure 1 Kaplan-Meier curves of OS, IDH2 codon 140. (A) Significant differences in OS between IDH2 codon 140 genotypes in intermediate risk AML patients. Median OS 6 vs. 18 months ( $p$ <.001) for IDH2 codon 140 mutated patients and wild-type patients, respectively. (B) OS for AML-patients with mutated or unmutated IDH2 codon 140 in the entire group, median OS 9 vs. 14 months, respectively $(p=0.278)$.

difference in patient median age at diagnosis compared to our study cohort, 43 vs. 64 years respectively. In the study of Patel et al. the patients' median age at diagnosis also was much lower than in our cohort, 48 vs. 64 years respectively. These may indicate that the effect of the $I D H 2$ mutations is seen in elderly patients.

Figueroa et al. [18] have shown that IDH mutant enzymes may result in a global DNA hypermethylation profile, 


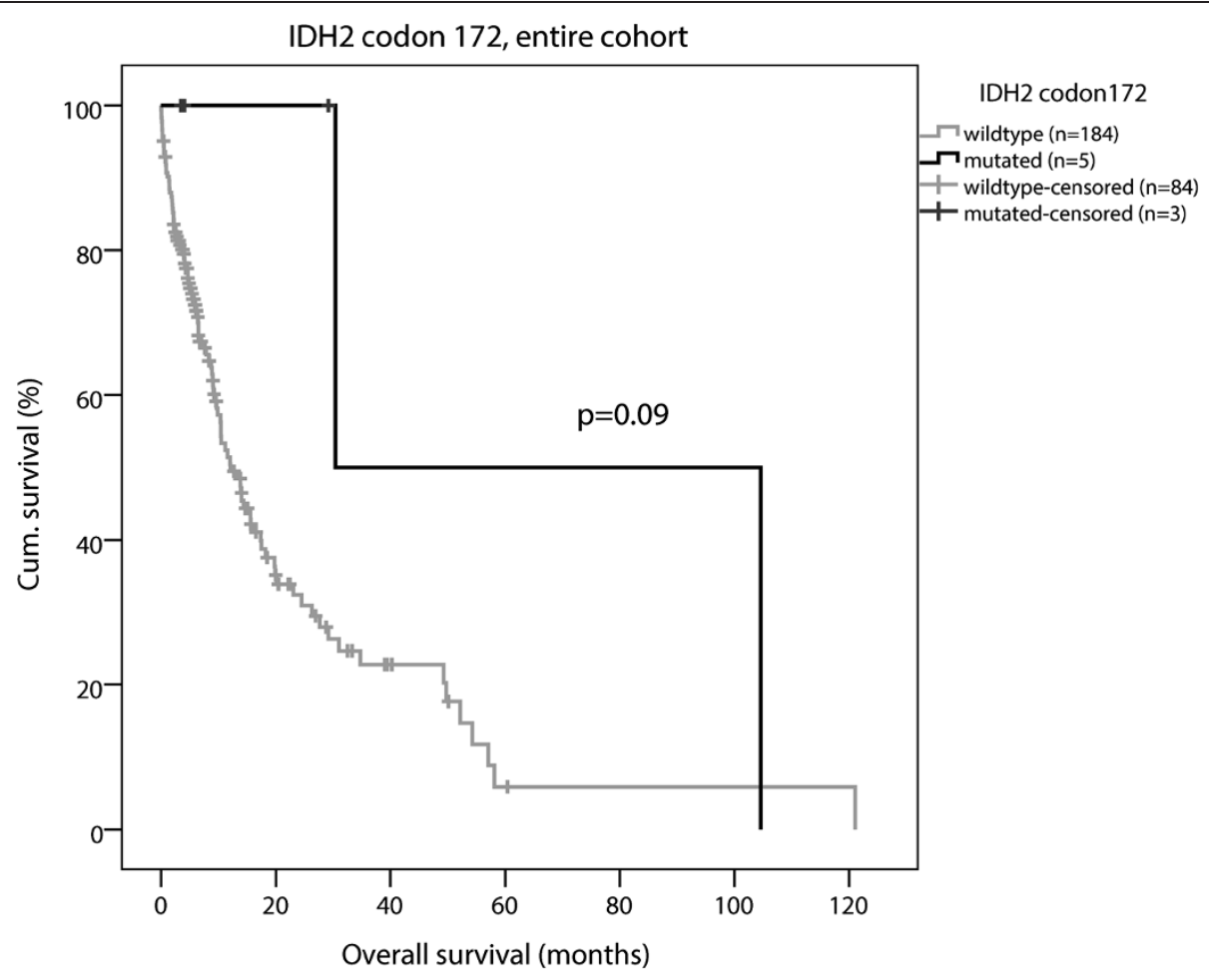

Figure 2 Kaplan-Meier curve of OS, IDH2 codon 172. The low frequency of AML-patients with mutated IDH2 codon 172 showed a tendency towards improved OS survival compared to wildtype IDH2, OS 30 vs. 12 months, $p=0.09$.

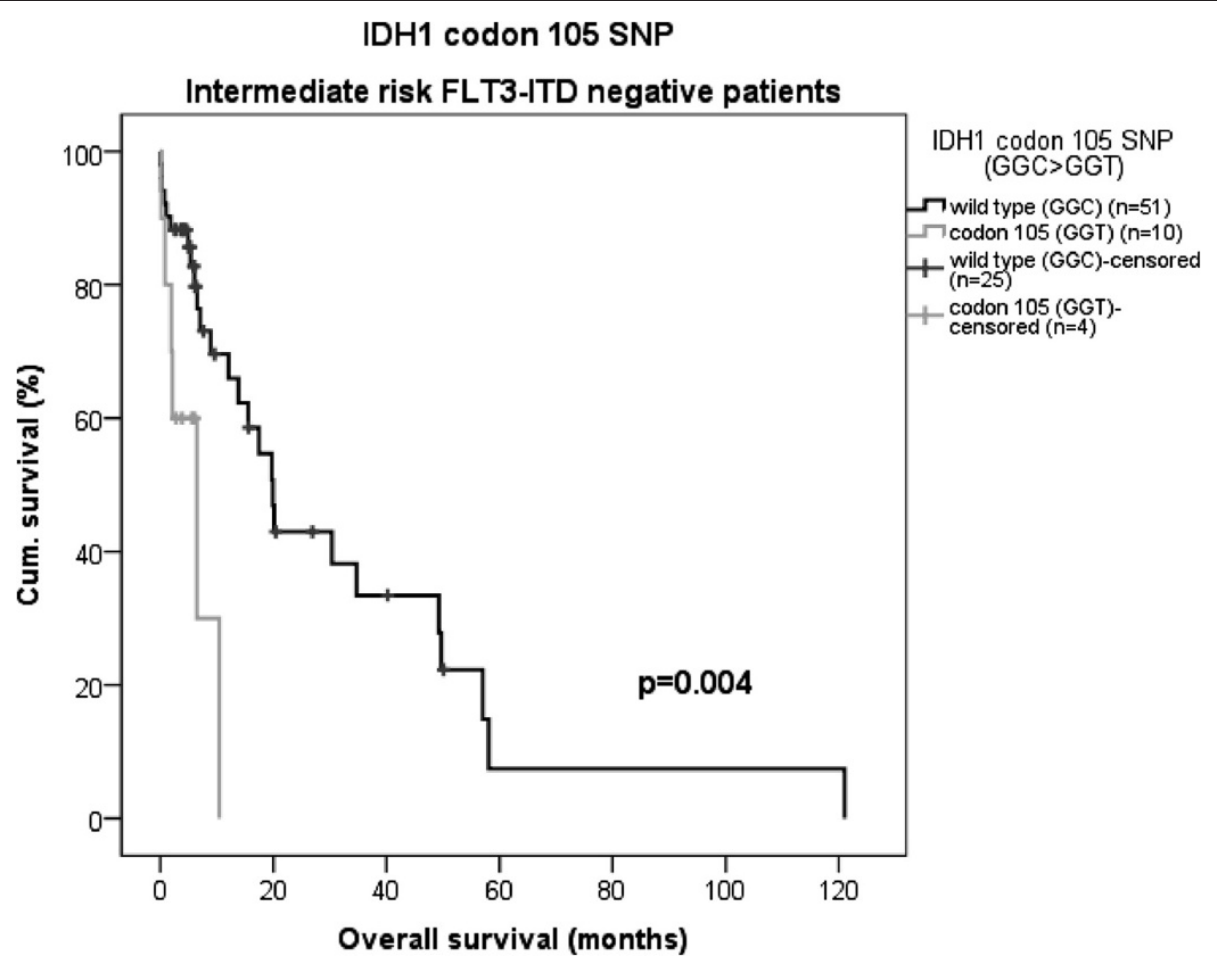

Figure 3 Kaplan-Meier curve of OS, IDH1 codon 105 SNP. Significant differences in OS between codon 105 genotypes in FLT3-ITD negative intermediate risk patients; median OS 6 vs. 20 months ( $p=0.004)$ for codon 105 variant allele and wild-type patients, respectively. 
blocking the cellular differentiation in hematopoietic cells through inhibition of demethylation of 5-metylcytosine (5-MeC) mediated via TET2. TET2 require $\alpha-K G$ for demethylation of $5-\mathrm{MeC}$ and, other studies have demonstrated that the mutation dependent metabolite $2-\mathrm{HG}$ is sufficient to promote leukemogenesis when mutated $I D H 1$ and IDH2 convert $\alpha-\mathrm{KG}$ to $2-\mathrm{HG}$ [30]. The TET2 gene is also identified to be mutated in de novo AML (7-23\%) and is mutually exclusive with $I D H 1 / 2$ mutations [31].

The synonymous SNP $105 \mathrm{C}>\mathrm{T}$, located in the same exon, but only overlapping in three cases, as R132 in the IDH1 gene, was also analyzed in our study. IDH2 mutations simultaneously with the codon 105 variant were found in three patients with codon 140 mutation and in one case with codon 172 mutation. The frequency of the SNP was $20 / 189(10.6 \%)$ in the entire cohort, and almost the same frequency $(11.7 \%)$ has been reported among healthy volunteers by a German group [20]. The same group also reported this SNP to correlate to an inferior prognosis in CN-AML [20]. In accordance with this, we found a pronounced significant inferior overall survival in intermediate risk FLT3-ITD negative patients carrying the variant codon 105 allele. The biologic effect of the silent SNP remains to be investigated in AML. One speculative explanation with a synonymous SNP is that it will cause a change in the rate of the protein translation resulting in affected protein folding and altered function of the protein [32], or cause a new splicing site. Potentially the $\mathrm{T}$ variant enables a new splice site (GTGG[C/T]ACGG > GTGgtacgg), resulting in a possible mRNA difference of $100 \mathrm{bp}$. Calculation of splice-site scores by using the Analyzer Splice Tool (http://ibis.tau.ac. $\mathrm{il} /$ ssat/SpliceSiteFrame.htm) would give a score of 72.5 to the potentially new splice site with the $\mathrm{T}$ variant compared with the natural splice site at the end of exon 4, which gives a score of 88.1. To test this possibly new splice site, we sequenced cDNA in three patients from this study with the $\mathrm{SNP} \mathrm{T}$ allele, but the results provided no difference in sequence length between the $\mathrm{C}$ or $\mathrm{T}$ alleles, and thus no new splice variant was detected.

In summary, our results identified in total $21.7 \%$ IDH1/IDH 2 mutations in the study population. Our results indicate that the IDH2 codon 140 mutation have the highest potential as a prognostic marker, further stratifying intermediate risk patients.

In addition, the synonymous SNP $105 \mathrm{C}>\mathrm{T}$ in the IDH1 gene may be a novel prognostic marker in AML of intermediate risk FLT3 negative patients however, this has to be confirmed through future studies. These markers may be especially useful in this heterogeneous group of AML patients, where other prognostic markers are absent and the outcomes vary widely. Further, studies have been carried out on possible new drugs by targeting the mutant IDH enzyme on leukemia cells, resulting in inhibition of accumulation of the 2-HG oncometabolite and subsequently differentiation of the AML blasts $[33,34]$.

\section{Conclusions}

IDH mutational status and/or IDH1 SNP $105 \mathrm{C}>\mathrm{T}$ variant may represent a new subgroup of AML patients and have the potential as tools for selecting patients expected to benefit the most from the new treatment alternatives.

\section{Methods}

\section{Patients}

This study included 189 Swedish patients diagnosed with de novo AML at Linköping University Hospital and Karolinska University Hospital in Huddinge between 1988 and 2010. The inclusion of the patients in this study was not consecutively included. Median age at diagnosis was 64 years, range 19-88 years. Patient characteristics are summarized in Table 2. Bone marrow or peripheral blood samples collected at diagnosis were used to isolate DNA for further genetic analysis. Risk group assignment at diagnosis was based on cytogenetic and molecular genetic findings as defined by ELN (European Leukemia Net) [35] and International Working Group recommendations [36], and other prognostic factors such as age, performance status and comorbidity, with minor modifications (see Swedish Hematology Association guidelines, http://www.sfhem.se/ Filarkiv/Nationella-riktlinjer accessed 2013-05-28). Swedish AML patients diagnosed in 2004 or later have been treated according to nationwide AML treatment guidelines (http:// www.sfhem.se/Filarkiv/Nationella-riktlinjer, accessed 201305-28). Thus, the majority of the patients received induction treatments including daunorubicin $60 \mathrm{mg} / \mathrm{m}^{2}$ once a day for three days combined with Cytarabine (AraC) as $1000 \mathrm{mg} / \mathrm{m}^{2}$ twice a day in $2 \mathrm{~h}$ i.v. infusions for 5 days. Before 2004, regional guidelines most commonly included AraC doses of $200 \mathrm{mg} / \mathrm{m}^{2}$ as 24 h i.v. infusions for 7 days combined with three days either daunorubicin or idarubicin [37]. Some patients also received other drugs in combination with daunorubicin/idarubicin and/or $\mathrm{AraC}$, such

\section{Table 4 Induction treatment regimes}

\begin{tabular}{ll}
\hline Regime & N (\%) \\
\hline $\begin{array}{l}\text { Daunorubicine and Cytarabine }(n=116) \text { or Daunorubicine, } \\
\text { cytarabine and mitoxantrone }(n=2)\end{array}$ & $118(62.4)$ \\
$\begin{array}{l}\text { Idarubicine and Cytarabine }(n=26) \text { or Idarubicine, } \\
\text { Cytarabine and Etoposide }(n=3)\end{array}$ & $29(15.3)$ \\
$\begin{array}{l}\text { Idarubicine, Cytarabine and Cladribine } \\
\text { Mitoxantrone, cytarabine and Etoposide }(n=7) \text { or }\end{array}$ & $20(10.6)$ \\
$\begin{array}{l}\text { Mitoxantrone and Cytarabine }(n=2) \\
\text { Daunorubicine, Cytarabine and 6-Thioguanine }\end{array}$ & $9(4.8)$ \\
Other/unknown & \\
\hline
\end{tabular}

'Including 2 in clinical trial of combination therapy with Tipifarnib, and 1 with Fludarabine, Cytarabine and G-CSF. 2 patients with unknown treatment but known curative intent. 
as Mitoxantrone, Etoposide, 6-Thioguanine and Cladribine. For further treatment details, see Table 4. Treatment response was evaluated as non-complete remission (no $\mathrm{CR}$ ) or morphologic complete remission (CR) [36]. Patients treated by allogeneic stem cell transplantation (alloSCT $)(n=59)$ were censored at the time of transplantation in the survival analysis. Informed consent was obtained from the patients and the study was approved by the local ethical committees and conducted in accordance with the Helsinki declaration.

\section{$I D H 1$ and IDH2 genotyping analysis}

Mononuclear cells from either peripheral blood or bone marrow were enriched by Ficoll-Paque density centrifugation at the time of diagnosis and genomic DNA was extracted. For $I D H 1$ and $I D H 2$ genotyping analysis, a PCR reaction was performed in a total volume of $20 \mu \mathrm{l}$ containing 10-50 ng DNA, 0.5U Taq DNA polymerase, $2 \mathrm{mM} \mathrm{MgCl}_{2}$, $0.2 \mathrm{mM}$ dNTPs, 1 xPCR buffer, $1 \mu \mathrm{M}$ each of $I D H 1$ forward primer (5'ctcagagccttcgctttctg) and reverse primer (5'cacatacaagttggaaatttctgg) and of IDH2 forward primer (5'ggggttcaaattctggttga) and reverse primer (5'ctaggcgaggagctccagt). The terminal cycling conditions for both $I D H 1$ and $I D H 2$ were an initial denaturation at $94^{\circ} \mathrm{C}$ for 2 min followed by 35 cycles at $94^{\circ} \mathrm{C}$ for $30 \mathrm{~s}, 55^{\circ} \mathrm{C}$ for $30 \mathrm{~s}$, $72^{\circ} \mathrm{C}$ for $30 \mathrm{~s}$ and an end extension at $72^{\circ} \mathrm{C}$ for $5 \mathrm{~min}$. The PCR product was purified by using ExoSAP-IT and direct sequencing was performed by using BigDye Terminator v3.1 Cycle Sequencing Kit (AB Applied Biosystems). The $I D H 1 / 2$ sequences were compared to the wild type IDH1/ 2 to detect the genetic variations (NM_005896.2 and NM_002168.2 respectively).

\section{Statistical analysis}

Fisher's exact test was used to compare differences in genotype distribution between patients with $\mathrm{CR}$ and no CR. Mann Whitney Test or Fisher's exact test was used to investigate differences between genotype groups in terms of age, gender and karyotype distributions, or other characteristics. Kaplan Meier survival analysis with log rank test for significance was used to evaluate the impact of $I D H 1$ and $I D H 2$ genotype on overall survival (OS) (calculated as time from diagnosis until death, date of the latest follow-up, or date of allo-SCT). Multivariable survival analysis was conducted using Cox regression with a forced entry method, taking age, risk group, treatment, $I D H 1 / 2$ mutations and $I D H 1$ SNP105 genotype into account. The impact of $I D H$ genotype was evaluated in the entire patient material and in subgroups stratified by risk group and FLT3 status. A $\mathrm{p}$-value of 0.05 was considered significant, and all analyses were performed using IBM SPSS Statistics v.20.

\section{Competing interests}

The authors declare that they have no competing interests.

\section{Authors' contributions}

K.W: Research, laboratory work, data compilation, manuscript writing; IJF: Resarch, clinical data compilation and statistical analysis, manuscript writing R.C: Clinical data compilation and consultation; E.P. Patient material and clinical data collection; M.H: FLT3/NPM1 analysis, data collection; H.G: Data and statistical analysis; K.L: Research, patient material and clinical data collection; P.S: Conception and study design, research. All authors critically reviewed the manuscript. All authors read and approved the final manuscript.

\section{Authors' information}

Kourosh Lotfi and Peter Söderkvist share last authorship.

\section{Acknowledgements}

This work was supported by grants from the Swedish Cancer Society, the County Council of Östergötland, AFA Insurance, Stockholm Cancer Society, Karolinska Institutet, and the Swedish Research Council. The authors thank Annette Molbaek, Asa Schippert and Jenny Welander for advice and technical assistance. We would also like to thank Christer Paul, Hareth Nahi and Sofia Bengtzén, Karolinska Institutet, for help with sample collection, clinical data, and technical assistance.

\section{Author details}

'Department of Clinical and Experimental Medicine, Linköping University, Linköping, Sweden. ${ }^{2}$ Department of Medical and Health Sciences, Linköping University, Linköping, Sweden. ${ }^{3}$ Department of Hematology, County Council of Östergötland, Linköping, Sweden. ${ }^{4}$ Division of Hematology, Department of Medicine, Karolinska Institutet, Huddinge, Stockholm, Sweden. ${ }^{5}$ Department of Immunology, Genetics and Pathology, Rudbeck Laboratory, Uppsala University, Uppsala, Sweden. ${ }^{6}$ Department of Forensic Genetics and Forensic Toxicology, National Board of Forensic Medicine, Linköping, Sweden.

${ }^{7}$ Department of Clinical Genetics, County Council of Östergötland, Linköping, Sweden.

Received: 19 August 2014 Accepted: 2 October 2014

Published: 8 October 2014

\section{References}

1. Grimwade D, Walker H, Oliver F, Wheatley K, Harrison C, Harrison G, Rees J, Hann I, Stevens R, Burnett A, Goldstone A: The importance of diagnostic cytogenetics on outcome in AML: analysis of 1,612 patients entered into the MRC AML 10 trial. The Medical Research Council Adult and Children's Leukaemia Working Parties. Blood 1998, 92:2322-2333.

2. Grimwade D, Walker H, Harrison G, Oliver F, Chatters S, Harrison CJ, Wheatley K, Burnett AK, Goldstone AH: The predictive value of hierarchical cytogenetic classification in older adults with acute myeloid leukemia (AML): analysis of 1065 patients entered into the United Kingdom Medical Research Council AML11 trial. Blood 2001, 98:1312-1320.

3. Bacher U, Haferlach T, Schoch C, Kern W, Schnittger S: Implications of NRAS mutations in AML: a study of 2502 patients. Blood 2006, 107:3847-3853.

4. Stone RM: The difficult problem of acute myeloid leukemia in the older adult. CA Cancer J Clin 2002, 52:363-371.

5. Falini B, Mecucci C, Tiacci E, Alcalay M, Rosati R, Pasqualucci L, La Starza R, Diverio D, Colombo E, Santucci A, Bigerna B, Pacini R, Pucciarini A, Liso A, Vignetti M, Fazi P, Meani N, Pettirossi V, Saglio G, Mandelli F, Lo-Coco F, Pelicci PG, Martelli MF: Cytoplasmic nucleophosmin in acute myelogenous leukemia with a normal karyotype. N Engl J Med 2005, 352:254-266.

6. Bienz M, Ludwig M, Leibundgut EO, Mueller BU, Ratschiller D, Solenthaler M, Fey MF, Pabst T: Risk assessment in patients with acute myeloid leukemia and a normal karyotype. Clin Cancer Res 2005, 11:1416-1424.

7. Nakao M, Yokota S, Iwai T, Kaneko H, Horiike S, Kashima K, Sonoda Y, Fujimoto T, Misawa S: Internal tandem duplication of the flt3 gene found in acute myeloid leukemia. Leukemia 1996, 10:1911-1918.

8. Mrozek K, Marcucci G, Paschka P, Whitman SP, Bloomfield CD: Clinical relevance of mutations and gene-expression changes in adult acute myeloid leukemia with normal cytogenetics: are we ready for a prognostically prioritized molecular classification? Blood 2007, 109:431-448.

9. Mardis ER, Ding L, Dooling DJ, Larson DE, McLellan MD, Chen K, Koboldt DC, Fulton RS, Delehaunty KD, McGrath SD, Fulton LA, Locke DP, Magrini VJ, Abbott RM, Vickery TL, Reed JS, Robinson JS, Wylie T, Smith SM, Carmichael L, Eldred JM 
Harris CC, Walker J, Peck JB, Du F, Dukes AF, Sanderson GE, Brummett AM, Clark E, McMichael JF, et al: Recurring mutations found by sequencing an acute myeloid leukemia genome. N Engl J Med 2009, 361:1058-1066.

10. Dang $L$, Jin S, Su SM: IDH mutations in glioma and acute myeloid leukemia. Trends Mol Med 2010, 16:387-397.

11. Sanson M, Marie Y, Paris S, Idbaih A, Laffaire J, Ducray F, El Hallani S, Boisselier B, Mokhtari K, Hoang-Xuan K, Delattre JY: Isocitrate dehydrogenase 1 codon 132 mutation is an important prognostic biomarker in gliomas. J Clin Oncol 2009, 27:4150-4154.

12. Yan H, Parsons DW, Jin G, McLendon R, Rasheed BA, Yuan W, Kos I, BatinicHaberle I, Jones S, Riggins GJ, Friedman H, Friedman A, Reardon D, Herndon J, Kinzler KW, Velculescu VE, Vogelstein B, Bigner DD: IDH1 and IDH2 mutations in gliomas. N Engl J Med 2009, 360:765-773.

13. Marcucci G, Maharry K, Wu YZ, Radmacher MD, Mrozek K, Margeson D, Holland KB, Whitman SP, Becker H, Schwind S, Metzeler KH, Powell BL, Carter TH, Kolitz JE, Wetzler M, Carroll AJ, Baer MR, Caligiuri MA, Larson RA, Bloomfield CD: IDH1 and IDH2 gene mutations identify novel molecular subsets within de novo cytogenetically normal acute myeloid leukemia: a Cancer and Leukemia Group B study. J Clin Oncol 2010, 28:2348-2355.

14. Boissel N, Nibourel O, Renneville A, Gardin C, Reman O, Contentin N, Bordessoule D, Pautas C, de Revel T, Quesnel B, Huchette P, Philippe N, Geffroy S, Terre C, Thomas X, Castaigne S, Dombret H, Preudhomme C: Prognostic impact of isocitrate dehydrogenase enzyme isoforms 1 and 2 mutations in acute myeloid leukemia: a study by the Acute Leukemia French Association group. J Clin Oncol 2010, 28:3717-3723.

15. Paschka P, Schlenk RF, Gaidzik VI, Habdank M, Kronke J, Bullinger L, Spath D, Kayser S, Zucknick M, Gotze K, Horst HA, Germing U, Döhner H, Döhner K: IDH1 and IDH2 mutations are frequent genetic alterations in acute myeloid leukemia and confer adverse prognosis in cytogenetically normal acute myeloid leukemia with NPM1 mutation without FLT3 internal tandem duplication. J Clin Oncol 2010, 28:3636-3643.

16. Dang L, White DW, Gross S, Bennett BD, Bittinger MA, Driggers EM, Fantin VR, Jang HG, Jin S, Keenan MC, Marks KM, Prins RM, Ward PS, Yen KE, Liau LM, Rabinowitz JD, Cantley LC, Thompson CB, Vander Heiden MG, Su SM: Cancer-associated IDH1 mutations produce 2-hydroxyglutarate. Nature 2009, 462:739-744.

17. Ward PS, Patel J, Wise DR, Abdel-Wahab O, Bennett BD, Coller HA, Cross JR, Fantin VR, Hedvat CV, Perl AE, Rabinowitz JD, Carroll M, Su SM, Sharp KA, Levine RL, Thompson CB: The common feature of leukemia-associated $\mathrm{IDH} 1$ and IDH2 mutations is a neomorphic enzyme activity converting alpha-ketoglutarate to 2-hydroxyglutarate. Cancer Cell 2010, 17:225-234.

18. Figueroa ME, Abdel-Wahab O, Lu C, Ward PS, Patel J, Shih A, Li Y, Bhagwat N, Vasanthakumar A, Fernandez HF, Tallman MS, Sun Z, Wolniak K, Peeters JK, Liu W, Choe SE, Fantin VR, Paietta E, Löwenberg B, Licht JD, Godley LA, Delwel R, Valk PJ, Thompson CB, Levine RL, Melnick A: Leukemic IDH1 and IDH2 mutations result in a hypermethylation phenotype, disrupt TET2 function, and impair hematopoietic differentiation. Cancer Cell 2010, 18:553-567.

19. Xu W, Yang H, Liu Y, Yang Y, Wang $P$, Kim SH, Ito S, Yang C, Xiao MT, Liu LX, Jiang WQ, Liu J, Zhang JY, Wang B, Frye S, Zhang Y, Xu YH, Lei QY, Guan KL, Zhao SM, Xiong Y: Oncometabolite 2-hydroxyglutarate is a competitive inhibitor of alpha-ketoglutarate-dependent dioxygenases. Cancer Cell 2011, 19:17-30.

20. Wagner K, Damm F, Gohring G, Gorlich K, Heuser M, Schafer I, Ottmann O, Lubbert M, Heit W, Kanz L, Schlimok G, Raghavachar AA, Fiedler W, Kirchner HH, Brugger W, Zucknick M, Schlegelberger B, Heil G, Ganser A, Krauter J: Impact of IDH1 R132 mutations and an IDH1 single nucleotide polymorphism in cytogenetically normal acute myeloid leukemia: SNP rs11554137 is an adverse prognostic factor. J Clin Oncol 2010, 28:2356-2364.

21. Ho PA, Kopecky KJ, Alonzo TA, Gerbing RB, Miller KL, Kuhn J, Zeng R, Ries RE, Raimondi SC, Hirsch BA, Oehler V, Hurwitz CA, Franklin JL, Gamis AS, Petersdorf SH, Anderson JE, Godwin JE, Reaman GH, Willman CL, Bernstein ID, Radich JP, Appelbaum FR, Stirewalt DL, Meshinchi S: Prognostic implications of the IDH1 synonymous SNP rs11554137 in pediatric and adult AML: a report from the Children's Oncology Group and SWOG. Blood 2011, 118:4561-4566.

22. Rakheja D, Konoplev S, Medeiros $L$, Chen W: IDH mutations in acute myeloid leukemia. Hum Pathol 2012, 43:1541-1551.

23. Schnittger S, Haferlach C, Ulke M, Alpermann T, Kern W, Haferlach T: IDH1 mutations are detected in $6.6 \%$ of $1414 \mathrm{AML}$ patients and are associated with intermediate risk karyotype and unfavorable prognosis in adults younger than 60 years and unmutated NPM1 status. Blood 2010, 116:5486-5496.
24. Chou WC, Lei WC, Ko BS, Hou HA, Chen CY, Tang JL, Yao M, Tsay W, Wu SJ, Huang SY, Hsu SC, Chen YC, Chang YC, Kuo KT, Lee FY, Liu MC, Liu CW, Tseng MH, Huang CF, Tien HF: The prognostic impact and stability of Isocitrate dehydrogenase 2 mutation in adult patients with acute myeloid leukemia. Leukemia 2011, 25:246-253.

25. Patel KP, Ravandi F, Ma D, Paladugu A, Barkoh BA, Medeiros LJ, Luthra R: Acute myeloid leukemia with IDH1 or IDH2 mutation: frequency and clinicopathologic features. Am J Clin Pathol 2011, 135:35-45.

26. Chotirat S, Thongnoppakhun W, Promsuwicha O, Boonthimat C, Auewarakul $\mathrm{CU}$ : Molecular alterations of isocitrate dehydrogenase 1 and 2 (IDH1 and $\mathrm{IDH} 2$ ) metabolic genes and additional genetic mutations in newly diagnosed acute myeloid leukemia patients. J Hematol Oncol 2012, 5:5

27. Green CL, Evans CM, Zhao L, Hills RK, Burnett AK, Linch DC, Gale RE: The prognostic significance of IDH2 mutations in AML depends on the location of the mutation. Blood 2011, 118:409-412.

28. Abbas S, Lugthart S, Kavelaars FG, Schelen A, Koenders JE, Zeilemaker A, van Putten WJ, Rijneveld AW, Lowenberg B, Valk PJ: Acquired mutations in the genes encoding IDH1 and IDH2 both are recurrent aberrations in acute myeloid leukemia: prevalence and prognostic value. Blood 2010, 116:2122-2126.

29. Patel JP, Gonen M, Figueroa ME, Fernandez H, Sun Z, Racevskis J, Van Vlierberghe P, Dolgalev I, Thomas S, Aminova O, Huberman K, Cheng J, Viale A, Socci ND, Heguy A, Cherry A, Vance G, Higgins RR, Ketterling RP, Gallagher RE, Litzow M, van den Brink MR, Lazarus HM, Rowe JM, Luger S, Ferrando A, Paietta E, Tallman MS, Melnick A, Abdel-Wahab O, et al: Prognostic relevance of integrated genetic profiling in acute myeloid leukemia. N Engl J Med 2012, 366:1079-1089.

30. Losman JA, Looper RE, Koivunen P, Lee S, Schneider RK, McMahon C, Cowley GS, Root DE, Ebert BL, Kaelin WG Jr: (R)-2-hydroxyglutarate is sufficient to promote leukemogenesis and its effects are reversible. Science 2013, 339:1621-1625.

31. Gaidzik VI, Paschka P, Spath D, Habdank M, Kohne CH, Germing U, von Lilienfeld-Toal M, Held G, Horst HA, Haase D, Bentz M, Götze K, Döhner H, Schlenk RF, Bullinger L, Döhner K: TET2 mutations in acute myeloid leukemia (AML): results from a comprehensive genetic and clinical analysis of the AML study group. J Clin Oncol 2012, 30:1350-1357.

32. Kimchi-Sarfaty C, Oh JM, Kim IW, Sauna ZE, Calcagno AM, Ambudkar SV, Gottesman MM: A "silent" polymorphism in the MDR1 gene changes substrate specificity. Science 2007, 315:525-528.

33. Wang F, Travins J, DeLaBarre B, Penard-Lacronique V, Schalm S, Hansen E, Straley K, Kernytsky A, Liu W, Gliser C, Yang H, Gross S, Artin E, Saada V, Mylonas E, Quivoron C, Popovici-Muller J, Saunders JO, Salituro FG, Yan S, Murray S, Wei W, Gao Y, Dang L, Dorsch M, Agresta S, Schenkein DP, Biller SA, Su SM, de Botton S, et al: Targeted inhibition of mutant IDH2 in leukemia cells induces cellular differentiation. Science 2013, 340:622-626.

34. Kats LM, Reschke M, Taulli R, Pozdnyakova O, Burgess K, Bhargava P, Straley K, Karnik R, Meissner A, Small D, Su SM, Yen K, Zhang J, Pandolfi PP: Proto-oncogenic role of mutant IDH2 in leukemia initiation and maintenance. Cell Stem Cell 2014, 14:329-341.

35. Dohner H, Estey EH, Amadori S, Appelbaum FR, Buchner T, Burnett AK, Dombret H, Fenaux P, Grimwade D, Larson RA, Lo-Coco F, Naoe T, Niederwieser D, Ossenkoppele GJ, Sanz MA, Sierra J, Tallman MS, Löwenberg B, Bloomfield CD: Diagnosis and management of acute myeloid leukemia in adults: recommendations from an international expert panel, on behalf of the European LeukemiaNet. Blood 2010, 115:453-474.

36. Cheson BD, Bennett JM, Kopecky KJ, Buchner T, Willman CL, Estey EH, Schiffer CA, Doehner H, Tallman MS, Lister TA, Lo-Coco F, Willemze R, Biondi A, Hiddemann W, Larson RA, Löwenberg B, Sanz MA, Head DR, Ohno R, Bloomfield CD: Revised recommendations of the International Working Group for Diagnosis, Standardization of Response Criteria, Treatment Outcomes, and Reporting Standards for Therapeutic Trials in Acute Myeloid Leukemia. J Clin Oncol 2003, 21:4642-4649.

37. Wahlin A, Billstrom R, Bjor O, Ahlgren T, Hedenus M, Hoglund M, Lindmark A, Markevarn B, Nilsson B, Sallerfors B, Brune M: Results of risk-adapted therapy in acute myeloid leukaemia. A long-term population-based follow-up study. Eur J Haematol 2009, 83:99-107.

doi:10.1186/2050-7771-2-18

Cite this article as: Willander et al:: Mutations in the isocitrate dehydrogenase 2 gene and $I D H 1$ SNP $105 C>T$ have a prognostic value in acute myeloid leukemia. Biomarker Research 2014 2:18. 